\title{
The foreign language student as an ethnographer: language games and ethnographic techniques for enhancing the development of intercultural competence through studying foreign language culture
}

\begin{abstract}
The present paper aims at finding ways to solve the problem of how to teach culture, showing the connections between culture and language, while at the same time striving to develop intercultural competence. In the author's opinion, the ethnography of speaking is the answer. Starting with an overview of what ethnography offers to intercultural communicative competence, this paper supports the idea of implementing an approach close to the ethnography of speaking and shows how linguistic ethnography might be implemented into the study of culture in order to show the relationships between language use, cultural behavior and values. This approach rests upon the belief that the implicit knowledge applied in use of a language needs deeper analysis in order to enhance students' symbolic competence, which in turn enhances their intercultural competence. Examples used in the analysis to justify this claim derive from material used during a course in General English, or courses of British and American Studies. The concept of language-games as proposed by Wittgenstein, who pays attention to the context of language use at the micro level, is applied. The suggestion is to position this analysis in the field of the ethnography of speaking, or linguistic ethnography, and extend the role of a student to one of a linguistic ethnographer. Ethnographic techniques implemented in the analysis of language use and its context might contribute to the development of symbolic competence as complementary to intercultural communicative competence.
\end{abstract}


Keywords: FL learner, ethnography of speaking, language games, intercultural communicative competence, symbolic competence

Słowa kluczowe: uczeń języka obcego, etnografia mowy, gry językowe, interkulturowa kompetencja komunikacyjna, kompetencja symboliczna

The essential vocation of interpretive anthropology is not to answer our deepest questions, but to make available to us answers that others, guarding other sheep in other valleys, have given, and thus to include them in the consultable record of what man has said

(Clifford Geertz, 1973 :30)

\section{Introduction}

Teaching culture as a complementary but integral element of foreign language education (Crozet and Liddicoat, 1997; Chan et al., 2015:1) necessitates adopting an approach within which cultural content will be delivered and subsequently analysed. This claim is strengthened by the fact that culture and language are interwoven entities, but also as second (foreign) language learning involves the appropriation of cultural meaning (Chan et al., 2015:8). The justification for integrating culture with language learning can be found in many works of various scholars (see Chan et al., 2015:2). The integration of language learning and teaching and culture is achieved by use of various approaches and techniques, which Risager (2011: 485) calls cultural dimensions. She lists seven different perspectives and shows that authors most often apply a mixture of these in their incorporation of culture into language teaching and learning (Risager, 2011).

In the Polish academic context two approaches to culture teaching can be noted. One is the so-called academic approach and the other is the vocational approach. In the former, the emphasis is on the intellectual development of a student and studies focus either on the presentation of life and institutions in a particular country, or on culture within the field of so- called cultural studies (Green, 1999). In the vocational approach, aims and methods are tuned to the aims and methods used in training to develop professional skills, for example, those of a future language teacher, or translator.

According to studies conducted by Wilczyńska (2002), though this was limited to teacher trainees in the Teacher Training College in Poznań, most students prefer an academic approach (42\%), while only $12 \%$ value a vocational one. As regards the academic approach, there are those who prefer a culture teaching model based on the concept of life and institutions. Arthur Green (1999) clearly indicates that the so-called cultural studies are not good for Polish students. He believes cultural studies are not objective enough and follow academic fashions and political correctness. What a Polish student needs is facts and dates, Green (1999) adds. By 
contrast, Byram (1997a) presents some limitations to this kind of approach and claims that a course based on teaching about life and institutions does not allow one to dive deep into a culture and analyse its values and beliefs system.

But even if one decides to probe deeper to discover the system, one may not get straightforward answers. This can be illustrated by the example of queuing in Great Britain. Hofstede et al. (2000: 210) explain that "British queuing behavior is facilitated by the unemotional and patient nature of most British subjects." O'Driscoll (1995: 165) is of the opinion that ,[w]aiting for buses allows the British to indulge their supposed passion for queueing. Whether this really signifies civilized patience is debatable." Another remark made on the topic of queueing and which in my opinion explains the phenomenon well, is that a queue is a sign of equal status ascribed to members of society in a public space.

In the intercultural approach to language learning and teaching Liddicoat (2011: 837) notes there two approaches to incorporating culture into teaching. One is an approach which he terms cultural orientation. In this approach culture is not presented as directly linked to a language, and is taught separately of the language. The second option is intercultural orientation, which means decentering from one's own perspective and making an attempt to grasp the perspective of the other. Liddicoat (2011:838) claims

the learner needs to engage with language and culture and elements of a meaning-making system that influence and are influenced by each other. This means that language learning becomes a process of exploring the ways language and culture relate to lived realities.

This means that the learner needs to see and consequently explore the meaning that connects culture and language in interactions, as well as in other accompanying meaningful behaviours, like dress, facial expression or body language.

That appropriating only the knowledge of culture may be reductive is confirmed in the definition of intercultural communicative competence (ICC), where cultural knowledge is only one of its components (Byram, 1997b; Stier, 2006; Deardorff, 2011). The use of interpretative skills, one's attitude as well as cultural awareness are all at play in a communicative act. But the intercultural also needs the symbolic dimension (Kramsch, 2011: 366). As Kramsch and Whiteside (2008: 668) observe, "the late modern way of conceiving of both communicative and intercultural competence in multilingual settings is the notion of symbolic competence." This symbolic competence, on the one hand, rests upon an individual's ability to read a person's mindset through their words, and on the other hand, to at the same time acknowledge, the historical and social experiences at play. The symbolic network that a particular culture 
represents is shared by the people who use this code in their mutual practices to signify their meaning to other members of the group to which they belong (Geertz, 1973; Jenks, 1993; Turner, 2001; Knight, 2014). Thus, symbolic competence functions as a predisposition for the interpretation of meaning in interactions that, as Jenks (1993: 9) puts it, are "artful practices" to signify meaning.

In Polish education, the traditional model of teaching (Klus-Stańska, 2012) implies that bodies of knowledge are to be passed on to students. Absorbing cultural knowledge as a set of facts is still the dominant mode in students' attitudes towards studying culture, as a study on the role of texts used to teach culture in British Studies revealed (Owczarek, 2005: 100).

Bearing in mind that factual knowledge about a culture has some limitations when it comes to developing ICC and showing the relations between language and culture explicitly, this paper argues for the implementation of some techniques that will help explore the links between language and culture in culture teaching. Namely, the application of the ethnography of speaking is proposed. In particular, the concept of language games as developed by Wittgenstein is suggested within the field of linguistic ethnography. This, it is believed, will allow students to see how culture is linked to language and everyday practices.

First, the role of ethnography is discussed as a forerunner of ethnographic practices in FLT, before moving to an ethnography of speaking which reaches for language use and social practices situated in particular communicative contexts. The ethnography of speaking encompasses the gaps left out by conversational analysis (CA) or discourse analysis (DA) as it pays attention to context defined by sociolinguistic variables (Boxer, 2002:13; Waugh, 2016: 105). The concept of language games as developed by Wittgenstein is presented as one that may serve to fill this gap and contribute to enhancing the student's symbolic and intercultural communicative competence.

In the Polish educational setting, the teaching of factual knowledge and linguistic competence (preparation for exams) have traditionally been prioritized (Klus-Stańska, 2012; Aleksandrowicz-Pędich, 2007), an attitude which marginalizes development of ICC in FLT. Despite this, according to the Language Education Policy Profile report on language education in Poland 20052007 , the issue of intercultural competence is slowly gaining support in the educational context. The Language Education Policy Profile (2005-2007: 34) states that some institutions have introduced an intercultural module. However, in the vision for the future there is a recommendation that an intercultural perspective in teacher training should be adopted and there is also a suggestion for intercultural learning made in the guide section. In the Polish context, especially outside large urban centres, formal education plays a much bigger role than informal education in developing intercultural sensitivity (Romanowski, 2017). 
The foreign language student as an ethnographer: language games and...

The techniques proposed may help raise awareness of the conditions of a communicative act. They may also answer the call for constructing certain practice within "a theoretical orientation that frames options and principles that are to be adapted by teachers in their own location specific practices" (Liddicoat, 2011: 840).

\section{Ethnography as a technique for teaching "abstract culture"}

With the advent of the intercultural approach to language teaching the aim of language pedagogy was to develop intercultural communicative competence (ICC), which in Byram's model (1997) consists of five elements: attitudes, knowledge, skills for interpreting and relating, skills for discovering and interacting, as well as critical cultural awareness. The latter, which is understood as a critical evaluation of one's native and the foreign culture, has been regarded as a central concept of ICC (Byram, 2008: 162).

An intercultural approach to language pedagogy allows for the adoption of a holistic attitude that links language, culture, and society, and explains how these function together in communication. "Ethnography, the science and art of cultural description, analysis and interpretation" (Saravia-Shore, Arvizu, 2017: XXIII) may well accomplish this goal. The application of ethnographic practices to pursue a holistic goal has been advocated in numerous studies (Bandura, 2007; Byram, Fleming, 1997; Byram et al., 1994; Corbett, 2003; Roberts et al., 2001). The authors emphasize the fact that ethnographic practices conducted outside the classroom with the aim of making students aware of their own cultural practices, make them reflect on what they observe, and notice how the cultural behavior they observe influences their attitude towards it. Techniques which focus on students' own culture are called 'home ethnography' (Bandura, 2007; Roberts, 2001). This ethnographic orientation in FLT focuses on the direct experience of the home culture, if conducted at home, or of a foreign culture, if conducted during study abroad programmes (see Ryan, 2009).

It is often underlined that ethnographic practices have a larger impact on the development of a learner's ICC than the studying of texts for vocabulary and language skills in the communicative approach to language teaching. A student in the role of an ethnographer pays attention to verbal and nonverbal means of communication, discerns the known and the unknown and reflects upon it. This is the starting point to avoid generalizations about one's native culture and constitutes the grounds for comparing one's own culture with a foreign one. As Sapir (2002:44) puts it, "you observe behavior from which you extract culture." Thus, the educational aim of home ethnography is to raise cultural awareness, and the practical goal is to develop the skills of perceiving communication as a process composed of verbal and non-verbal 
practices (body language, eye contact, dress, various everyday practices) and their use to implicate meaning.

Becoming an ethnographer makes a foreign language learner better prepared for the role of a cultural mediator. This is a new role ascribed both to the learner and teacher in the intercultural approach to language teaching (Aleksandrowicz-Pędich, 2005; Bandura, 2007; Buttjes, Byram, 1990; Zawadzka, 2004). As an ethnographer of their own native culture, the foreign language learner conducts direct observations of the behavior of their community in small-scale entities such as a local shop, bakery, the underground station, or as was indicated earlier, a bus stop (Zarate, 1990: 249) Research on the role of ethnography in developing intercultural communicative competence has demonstrated its advantages in creating a more open attitude among students, such as their avoiding of stereotyping or making unjustified generalizations like "All people in my country..., , (Robin-Stuart, Nocon, 1996; Zarate, 1990). Ethnographic practices in a foreign language classroom develop the student's ability to understand their own culture better and improve their observation skills. Well-developed observation skills guarantee a more accurate investigation of a foreign culture, making comparison of that culture with one's own and enhance the experience of a foreign culture (see Lopez-Barrios, 2012; Reimann, 2010). Successful ethnographic observations may lead to the development of so-called critical cultural awareness of self (see Holmes and O'Neill, 2012). But unsuccessful ethnographic observations may also develop, or strengthen, a negative attitude towards a foreign culture if students are not prepared for this kind of activity (Liddicoat et al., 2003: 29).

This direct experience of one's native or the foreign culture can be supplemented by a culture studies orientation, which focuses on the analysis of texts, not only to extract factual knowledge but also "to explore cues which signal meanings in the text" (Liddicoat, 2011: 843). This focus on culture and language integration can be brought to the student's attention by analysis at "a surface sociolinguistic level" or at a deeper level through "the exploration of cultural values, concepts, and identities" (Liddicoat et al., 2003: 36).

\section{Reaching for symbolic competence: The role of the ethnography of speaking}

Ethnographic studies also deal with the analysis of language use. As Roberts (2001) convincingly argues, by taking on the role of an ethnographer of speaking, the language learner will move beyond the structural and the functional level in order to understand the complex intricacies of communication observed on the social level. Through language, its users express a set of values they believe in, mark boundaries among communities they live in, signal their belonging to a community and link reality to the concepts in their minds. According to Roberts (2001), ethnographic 
studies of language can boost students' competence in their understanding of how language is used to reflect, express and constitute reality (Roberts, 2001: 49). Roberts' proposal (2001) in this respect is to adopt conversational analysis (CA), or discourse analysis (DA) as the classroom teaching technique, together with ethnographic instructions on how to use them given in advance.

Another way to better understand and present language-culture relationships is the ethnography of speaking which focuses on the content and form or, as Newton et al. (2015: 22) say on "culture-bound assumptions", that may help explore and understand the complexities of communication. These language-culture relationships, which include eight dimensions (Newton et al., 2015: 25), of which the dimension of "how language use in bounded everyday uses of language reflects understanding of roles, rights and responsibilities" as well as "how messages are positioned in relation to addressees" (Newton et al., 2015: 19) are of particular interest for the considerations in this paper.

The ethnography of speaking "views discourse as one of the main loci for the (re)creation and transmission of cultural patterns of knowledge and social action." Attention is paid to "what is accomplished through speaking and how speech is related to and is constructed by particular aspects of social organization, speakers' assumptions, values and beliefs about the world" (Duranti, 2005: 17). Here, the question 'why this has been said' is often posed. As Duranti (2005: 19) further explains, the ethnography of speaking acknowledges Wittgenstein's claim that language use depends on the context of speaking. In other words, contexts of language use, which Wittgenstein terms as language-games, determine "how linguistic signs can do the work they do." In particular, language functions to designate social relationships and social identities and it depicts how the world functions. Language sets the frames in which a society and an individual operate, as well as controls it, breaking and sustaining cultural, political and social barriers.

Rosaldo (1982), underscores the fact that not only what is said, but also how it is said, is paramount. Following her line of reasoning, paying attention to what and how people talk can help us to better illustrate, explain and understand cultural phenomena. This attitude has been explored by Moerman (1988), who in his studies explains cultural phenomena by combining ethnography with conversational analysis. These examples serve to justify the claim that if one wants to learn about a foreign culture it is worth doing so from the perspective of the utterances of the people living in a given culture.

The phrase 'utterance' is used on purpose here to also take into account those examples in the ensuing analysis that do not accord with discourse analysis. 'Utterance' is broad enough to include words, a sentence or a group of sentences. Duszak (after Dobrzyńska, 1998:14) defines an utterance as a particular text, a specific 
verbal message provided by a speaker in a given communicative act, which is characterized by individual language use. As Kramsch and Whiteside (2008) note

[a]nalyzing exchanges between monolingual speakers of English, Gumperz (1982) found that the meanings of utterances there too lie not only in the way participants orient themselves to the ongoing exchange, but in the way they implicitly ventriloquate or even parody prior utterances and thereby create affordances in ways that are favorable to them.

Although utterance is a unit widely used in CA and DA, nevertheless CA and DA may not be sufficiently adequate for the analysis since CA focuses on a conversation without paying enough attention to the macro context, while DA does the opposite. Namely, in DA not enough attention is paid to the micro context (Copland, Creese, 2015; Fitch, Phillipsen, 2020; Frayne, 2017; Heller, 2011). However, utterance still appears to be a unit relevant to this investigation where the focus is on language as a carrier of the cultural values of a given society.

As Heller (2011: 35) remarks linguistic ethnographers see

the complex role of language in constructing the social organization of production and distribution of the various forms of symbolic and material resources essential to our lives and to our ability to make sense of the world around us.

Language is a social construct (Creese, Blackledge, 2015:21). Things happen in context and the use of social and linguistic practices depends on the conditions in which they are used. Therefore, particular linguistic resources and the needs to which they relate have to be observed. This means

recognizing that all accounts are just that: not transparent windows into the workings of intentionality, but rather narratives that allow for an adequate description of the phenomenon of interest, in the circumstances in which they occur (Heller, 2011:43-44).

The question of what and how or why things are said brings the ethnography of speaking closer to the concept of ICC, since intercultural communicative competence is about seeing the position taken in an utterance (Kramsch, 2013:68). In order to notice this position various factors need to be examined. These factors are very often expressed in an implicit way by means of cues, or other semiotic means available within language use, and other signs that create the context in which the communication takes place.

According to Copland and Creese (2015: 26) "linguistic ethnographers see attention to the sign in discourse as a means to linking to wider historical, 
social, political and cultural structures." Wittgenstein's concept of languagegames, whose operations and practices depend on the context of language use, allows the gap created by CA and DA to be bridged and the micro system of CA to be connected with the macro system of DA. Students who put to use the concept of language-games become linguistic ethnographers who struggle to discover language and culture connections and at the same time improve their intercultural communicative competence.

\section{Language and culture connection in Wittgenstein's language games}

Language-games in the context of applied linguistics are none other than conventionalized communicative actions, thanks to which the world is experienced (Hall, 2012: 7). As Hall (2012: 8) explains

language games which are conventionalised patterns of communicative action are shared by members of a culture group, embody particular definitions of the situations and meanings of possible actions and, more generally, particular ways of knowing, valuing and experiencing the world.

Language as a social action is used to construct relationships and identities and because of this may be referred to as representing forms of life. These arise out of the particular contexts in which language is used. As Ara clarifies (2006: 50) "the meaning depends on the context and relations in the game." The meaning is in the use of a word in a game, which is understood as a code or a conventionalized pattern. But since forms and uses of language are many and flexible, the intention and position taken in communication obtains meaning from the language and context put together. (Ara, 2006:51) Through the language-games belonging to a group, intentions and other social actions like revealing hope, sympathy, or persuasion, are marked, making language a specific form of life (Ara, 2006).

Language-games may also be looked upon as constituting ideology in the language; that is, they express the values and attitudes which differentiate societies. This is the case for Eriksen (1991), the Scandinavian social anthropologist, who defines culture as an ongoing interaction. This interaction is dependent upon the social, historical and cultural context in which the communication takes place. He notes that culture itself is a precondition for an interaction to occur, and adds that cultural differences may be noticed by means of a careful interpretation of internal ethnic contexts. An example he gives relates to political language use, or the way of speaking in which one's preferences are expressed. The meaning of a word becomes the particular use of the word 
in a specific micro-situation, and next may be translated into macro-situations (Eriksen, 1991; Barinaga, 2009).

Hence, language-games, as proposed by Wittgenstein, constitute an interesting theoretical approach to accomplishing the goal of understanding the symbolic dimension of culture through language, since they allow one to gain an insight into what people do with language from the level of particular words or simple sentences, which Wittgenstein names a primitive language game, and move to an advanced level where the ideology, social relations and identities inherent in a language can be uncovered.

Language-games are transmitted from generation to generation, but they also undergo modifications in order to adapt to changes in society. They guide the discursive practices in communities and, as language and culture are bound together, language games are seen as organic forms of first hand-experience and for that reason they create a diversity of overlapping systems within a community of culture, or across cultures, since people who speak the same language still differ in their education, upbringing and political views and may use different languages. For as Wittgenstein holds, language-games fulfil the need for, and at the same time correspond to, various human actions (Frayne, 2017; Ma, 2004).

In most cases language-games rest upon tacit knowledge. As Hall (2011) explains, they are conventionalized in historical codes of use. The more conventionalized, the more tacit the rules of their application are, as this implicit knowledge is collectively shared social background knowledge. As Leonhoff, (2011: 59) observes, for Wittgenstein communication is not based on rational explicit knowledge. Hence, Leonhoff (2011) concludes, attentiveness to the structure and function of implicit knowledge has a role to play in intercultural communication. The examples given below are to illustrate how attention to tacit knowledge might raise cultural awareness and reveal the nature of the relationships between language and culture for FL students.

In sum, it is believed that language-games allow a convincing presentation and explanation of the connections between language and culture within studies of culture and within an intercultural approach to language teaching and learning. Reflection is part of developing ICC, and "reflecting on what one's experience of linguistic and cultural diversity means for oneself", how one can reach beyond the structure to see this structure being put to use to express one's position, how history and economy play a role in expressing one's position (Liddicoat, 2011: 842) makes one understand the relations between language and culture. In other words, the application of languagegames to culture teaching in an intercultural approach in language pedagogy can be perceived as an attempt to construct more learning opportunities to develop students' symbolic competence in language learning programmes. 


\subsection{Language games in practice - discovering language and culture connections}

As Heller (2011: 37) observes, people may struggle over or negotiate ethnolinguistic categories such as food, who you marry, morals, or beliefs about the world. In their negotiations language is the medium through which they conduct this struggle. The examples provided below are used in British Studies, American Studies and General English courses taught at the university level. They have been selected to illustrate how language is used to construct or sustain social and political frames in society. They refer to a wide range of themes discussed in British and American Studies, such as the values shared in a particular community, social divisions, and ethnic and national identity. The material has been retrieved from internet sources, a feature film, and a private conversation. As Silverman (1993: 163) remarks,

[no] data can ever be said to be more 'natural' than any other-no data are untouched by human hands. So telephone conversations, for instance, are not intrinsically better sources of data than, say, research interviews, official statistics or fictional texts. In principle, it would seem, there are only good and bad methods of analysis - not good and bad data.

The internet as a source is particularly useful when we teach culture in a non-native environment and for many teachers it is an easily accessible and available source.

\subsubsection{Primitive language-games}

\section{Example 1}

In the scene below (adapted from the British film "The Full Monty") you can see two men balancing on top of a car floating in a canal in an industrial part of Sheffield. In the scene there is a short exchange of expressions between the two men standing on top of the car and a passer-by with a dog walking along the canal. The man walking the dog starts the conversation. What do the people say?

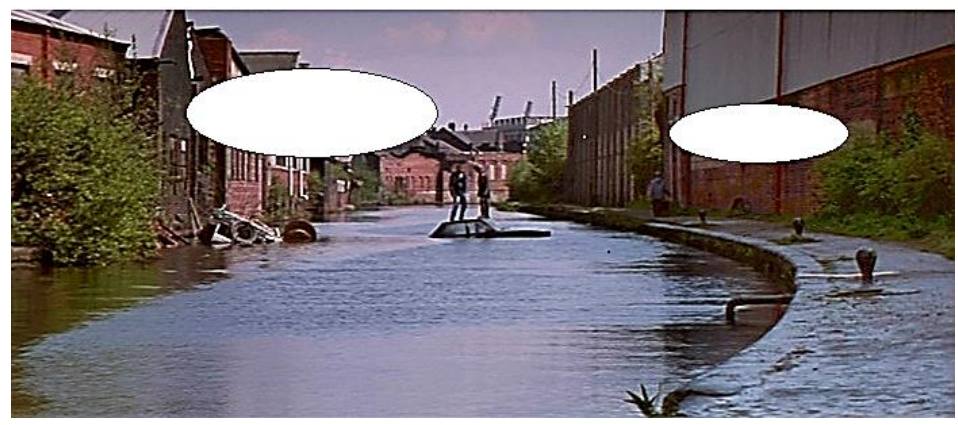

Fig. 1: A casual conversation (source: https://www.sheffieldhistory.co.uk/forums/topic/ 24-the-full-monty/). 


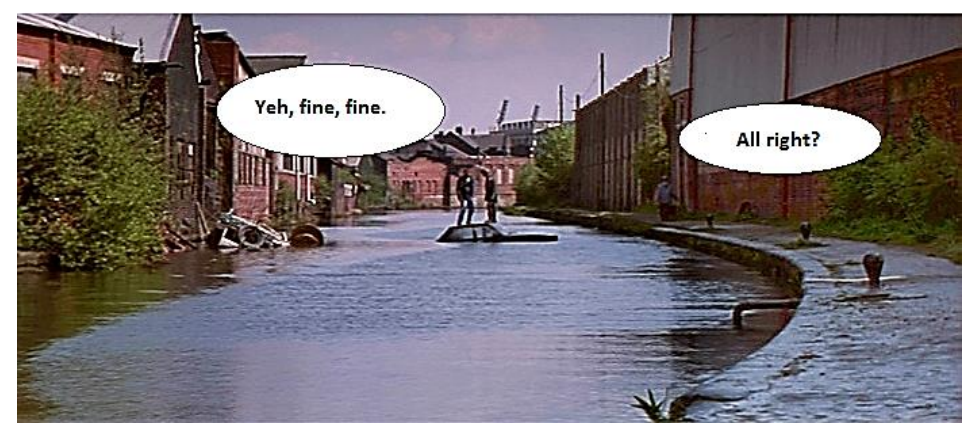

Fig. 2: A casual conversation: answer.

The formulaic exchange shows the cultural conditions of the people's verbal behavior, which in Britain tells people not to interfere in other people's business. The answers of Polish students ('What are you doing there?', 'You jerks, get off that car') point to Polish spontaneity, while the original English version points to the idea of arousing well-being (Wierzbicka, 1999).

\section{Example 2}

Below there are examples of inscriptions found on door hangers put up to celebrate Thanksgiving Day. The example is taken from a film Jenny's Wedding (2015).

Be grateful

Give thanks

These expressions point to the idea of encouraging people to care for others and ensuring the well-being of the community they live in (Grabowski, 2008: 26).

\section{Example 3}

There is great variety in the formulaic expressions used to greet a person in different parts of the USA. Below there are some examples of this behavior from The Geography of Small Talk (Wells, 2014).

Who do you belong to?

What are you?

Where did you go to school?/Where did you graduate from?

Where did you go to high school?

What do you do?

Where do you work?/What's your job?

What neighbourhood do you live in?

They are marked by the hidden intention of their users to establish the social status of the person they are talking to. 
The foreign language student as an ethnographer: language games and...

\section{Example 4}

Below there is a humorous application of a formulaic expression used by Graham Norton, host of the popular TV show The Graham Norton Show, (2013) to greet Robert De Niro, one of the guests on the programme.

G.N. If you were British, you would be called Sir Robert De Niro by now.

R.D. Call me Bob

This short exchange points to cultural differences in the recognition of merit in Great Britain and the USA. It also indirectly hints at the change of one's social status once merits have been recognized in Great Britain, which surfaces in British public discourse and stays hidden in the USA.

\section{Example 5}

The formulaic expression used to end a meeting organized in memory of political activist Frank La Mere, which took place during the presidential Native American forum (Indian Country Today, 2019).

"May our Creator be with each and every one of you and your families"

This formulaic expression in which the word creator is used signifies a cultural difference between the Native American community and the rest of American society through the use of the word 'Creator'. In Presidential speeches (see example 7 below) the word 'God' is used. As Prussing (2007) notices, the word 'Creator' appears, for example, in the narratives told by Native American women from the Cheyenne tribe.

\subsubsection{Advanced level language games}

In order to exemplify the idea of how language use handles the concept of the social structure in a given community, two example have been chosen, one from a radio programme and another from a private conversation.

\section{Example 6a}

An excerpt from a radio programme „Woman's Hour” broadcast on BBC 4 in the series called The Listening Project launched on 3 Jun 2012.

Betty had ten children [...]. She worked as a cook herself and often went without in order to put food on the table for her family. Her husband died a long time ago. She's now in her nineties but is independent as she always was. So if you ever find yourself thinking I don't have enough meal time, I can barely fit in a pedicure and how on earth am I going to find a fresh langoustine for the brunch party on Saturday this one is for you. 


\section{Example 6b}

A conversation between a Polish foreign language student (D.N. age 21) working abroad as an au pair in a rich Jewish family and her older friend (N.M) from the Lake District, northern England.

\section{N. M. Where do you work?}

D.N. I am an au pair in a Jewish family.

N.M. So now you can see how other people live.

D.N. But their life is like ours. They go to work, raise kids, etc.

In both examples there are references to the working and middle class. The first passage makes references to social class in Britain through the use of words such as langoustine or pedicure (the middle class-woman) on the one hand and suggests that both parties (the working class members and the middle class members) can look at each other with respect. The evidence for this is highlighted in the emphasis of Betty's independence, a working class woman.

Both examples show social divides in the U.K. and how these divides influence the perception of society. Language use is the expression of a worldview formed on the basis of common cultural experience at the core of which lies the conscious pursuit of interests of a particular class or group, which in these excerpts is questioned.

\section{Example 7}

An excerpt from the inaugural address delivered by Barak Obama on 20 Jan 2009 (American Rhetoric. Online Speech Bank, 2017).

We remain a young nation, but in the words of Scripture, the time has come to "set aside childish things." The time has come to reaffirm our enduring spirit; to choose our better history; to carry forward that precious gift, that noble idea, passed on from generation to generation: the God-given promise that all are equal, all are free, and all deserve a chance to pursue their full measure of happiness.

This excerpt from the President's speech provides an example of a language game that sets the boundaries for the entire American society. References to religion point to the historical roots of perceiving America as a special nation that will build a better and more equal society, the very essence of which derives from the Puritan idea voiced in a sermon with the phrase "We shall be a city upon a hill" delivered by John Winthrop, thus giving the myth of the American dream its Puritan roots (Grabowski, 2008: 32).

\section{Example 8}

Below are some people's opinions and associations with Thanksgiving celebrations (Cut 2015). 
The foreign language student as an ethnographer: language games and...

Family

Warm

That's a horror, horror beyond measure

Thanksgiving is the time when my family gets together and tell stories about our creation myths, and who we were, who we are and really what we lost. Inaccurate. I like the overall idea of Thanksgiving but not where it actually comes from.

On the one hand, the door hangers (see example 2) are, in a sense, the foundation of the myth, and these are common elements for the entire community, and the statements, like Family or Warm, uphold this myth in its positive dimension. Other utterances, like the word horror, are an attempt to falsify the myth and show the other side of the coin.

\section{Example 9}

Below there is an excerpt from a speech delivered at the Presidential Forum of the US Native Population in memory of Frank le Mary, 2019, by O. J. Semans, activist of the movement for improving voting conditions among native American citizens (Indian Country Today, 2019).

Let America know what we are asking. What we are asking is righteous and fair. If America heard this and they heard atrocities and how these treaties were violated they would say that's wrong. Do you believe we should have equality? 69\% agreed with us.[...]. It's not to teach candidates, it's to teach America.

In examples 5 and 7 the words Creator and God were used to mark ethnic boundaries. In example 9 the use of the pronoun 'we' and 'us' serves to mark an ethnic boundary for Native Americans against 'America' used as a third person singular. The speaker addresses the Native American audience and the language choices he makes in the speech make him more convincing and more devoted to the cause he is arguing for. All examples (5, 7 and 9) show how ethnic identity is signified through language. The Native American community is juxtaposed with the rest of American society. Language is used to mark a distinction between America and us (the Native American population). The text points to a separation between American native candidates for Congress and the rest of the country, called America.

Example 10

The passage below comes from the song "I'm not racist" by Joyner Lucas. The song itself had a mixed reception in the US. The lyrics, however, make it possible to look at certain contradictions expressed in it regarding the use of one particular word (Lucas, 2017). 


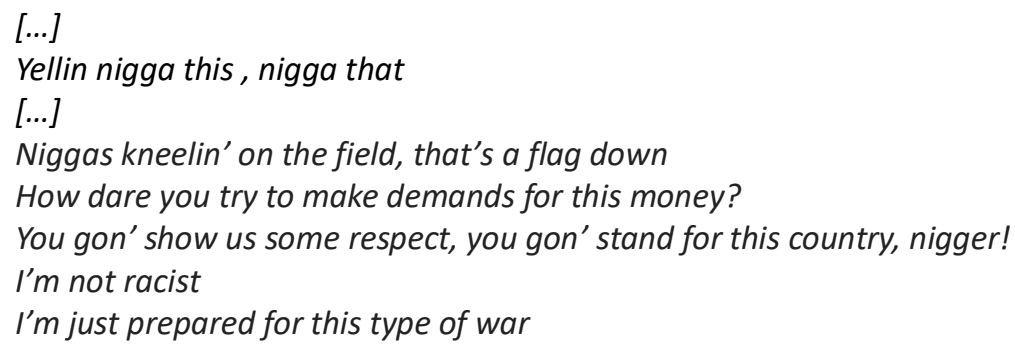

The use of the word ending in -er means that the one who uses the word contradicts himself when he later utters the phrase 'I' $m$ not racist'. The social divisions are hidden in this one particular word.

\section{Example 11}

Below there is a fragment of a conversation between Graham Norton, the host of the Programme The Graham Norton Show (2015) and his guest Michael Ryan Flatley, an Irish-American former dancer, choreographer and musician known worldwide for the Irish dance shows Riverdance, Lord of the Dance, Feet of Flames and Celtic Tiger Live.

G.N. [You own] a stately home in Ireland

M.F. The original house of the president of Ireland, Douglas Hyde, in Cork, on the Black Water river [...] I did it for Ireland.

GN. You will need a kettle here, here, and here to ensure a hot cup of tea MF. We have Guinness taps in these locations.

Michael Ryan Flatley's response points to a long Irish struggle to preserve national heritage and identity. Indirectly, it also shows the connections between the Irish American community and the Irish people living in Ireland. The passage may serve as a good starting point for a discussion about Irish (Guinness) and British (tea) relations.

\subsubsection{Advanced language-games with extended meaning of the key word}

\section{Example 12}

A post in a blog submitted by Claire Marie on Sat, 12/15/2012, American Road Trip is quoted below. The page does not exist now.

I want to start off this post with mentioning that I'm a New Yorker. One of the moments (in the book Travels with Charley) I personally found interesting was when a local said that it was the 'New York Jews' that were stirring up the trouble. It was a way to scapegoat a group of people without addressing the true issue at hand. The villainization of the North was something very real and it 
does exist today, though to a lesser extent. (Northerners don't always paint a nice picture of the South either, to be fair). I can understand how the North would seem like the enemy as it represents change that some of the South wasn't ready for.

The relations between the North and the South are explained by the use of the word 'villainization' derived from the word 'villain', which MerriamWebster Dictionary defines as a person blamed for a particular evil or difficulty. Geographical divides exist all over the world. But this particular example of the divide in the USA makes a good starting point for a deeper discussion on the relationships between the North and the South, pointing also to the changes that can presently be observed and to the past that had impact on these relationships.

\section{Conclusions}

In the intercultural approach to language and culture teaching, suggestions have been made to incorporate ethnographic techniques in the language classroom. Some refer to making discoveries about one's native culture. Some suggestions refer to incorporating CA and DA. This paper purports to show how the concept of the 'language- game' can enrich the studying of culture and expose its symbolic dimension. That the intercultural approach needs the symbolic has been emphasized already by Kramsch (2011) who observes that

[i]f intercultural competence is the ability to reflect critically or analytically on the symbolic systems we use to make meaning, we are led to reinterpret the learning of foreign languages as not gaining a mode of communication across cultures, but more as acquiring a symbolic mentality that grants as much importance to subjectivity and the historicity of experience as to the social conventions and the cultural expectations of any one stable community of speakers (Kramsch, 2011: 365).

So the question arises: how do we teach culture so that the 21st century becomes the era of cultural mediators in an increasingly multicultural society? It is not easy to fight the traditional model based on providing declarative knowledge. But despite a common belief in the model's strength, I think that the suggestions for a language and culture tandem presented above can enrich students' experience of culture learning, and help educate a society that is more aware of their actions and capable of responding to the needs of the 21st century in a more conscious way.

The examples provided in this paper could be the subject of sociolinguistic scrutiny. But they could also constitute an analysis of utterances in 
courses run to teach foreign cultures. Classes where such practices are undertaken raise the awareness of connections between culture and language and in a practical way allow a teacher to show how strong the relationship between language and culture is, how language becomes a carrier of culture and the role it plays in sustaining social values and relations, and how through language speakers fight to change them.

The author of this paper believes that further research on the subject of teaching and exploring relationships between language and culture in the FL classroom using the concept of language-games is needed. A comprehensive project conducted for one semester can provide a more reliable answer to the question whether the ethnographic techniques suggested work well and are useful for students. This project, together with the assessment of the outcomes of the project, should yield more reliable data as to the legitimacy of the ideas considered in this paper.

\section{BIBLIOGRAPHY}

Aleksandrowicz-Pędich L. (2005), Międzykulturowość na lekcjach języków obcych. Białystok: Wydawnictwo Uniwersytetu w Białymstoku.

Aleksandrowicz-Pędich L. (2007), Interkulturowość w kształceniu językowym w Polsce innych krajach europejskich, (in:) Komorowska H. (ed.), Nauczanie języków obcych. Polska Europa. Warszawa: ACADEMICA, pp. 39-56.

American Rhetoric. Online Speech Bank (2017), Barak Obama. First Presidential Inaugural Address. "What is Required: The Price and Promise of Citizenship.". Online: https://americanrhetoric.com/speeches/barackobama/barackobamainauguraladdress.htm [Accessed 20.04.2020].

Ara R. (2006), Wittgenstein's concepts of language games. "Al-Hikmat", No 26, pp. 47-62.

Bandura E. (2007), Nauczyciel jako mediator kulturowy. Kraków: Tertium.

Barinaga E. (2009), A performative view of language-methodological considerations and consequences for the study of culture. "FQS", No 10(1). Online: http://www.qualitativeresearch.net/index.php/fqs/article/view/ 1226/2667\#footnoteanchor_2 [Accessed 10.01.2020].

Boxer D. (2002), Applying sociolinguistics. Domain and face-to-face interaction. Amsterdam/Philadelphia: John Benjamins Publishing Company.

Buttjes D., Byram M. (1990), Mediating languages and cultures: towards an intercultural theory of foreign language education. Clevedon: Multilingual Matters

Byram M. (1997a), Cultural studies in foreign language teaching, (in:) Bassnett S. (ed.), Studying British cultures. London: Routledge, pp. 56-67. 
The foreign language student as an ethnographer: language games and...

Byram M. (1997b), Teaching and assessing intercultural communicative competence. Clevedon: Multilingual Matters.

Byram M., Morgan, C. (1994), Teaching-and-learning Language-and-culture. Clevedon: Multilingual Matters.

Byram M. (2008), From foreign language education to education for intercultural citizenship. Essays and reflections. Clevedon: Multilingual Matters. Chan W. M. et al. (2015), Culture and foreign language education: insights from research and implications for the practice. Boston/Berlin: Walter de Gruyter.

Copland F., Creese A. (2015), Linguistic ethnography: collecting, analysing and presenting data. London: Sage.

Creese A., Blackledge A. (2015), Translanguaging and identity in educational settings. "Annual Review of Applied Linguistics", No 35, pp. 20-35.

Crozet C., Liddicoat A. (1997), Teaching culture as an integrated part of language teaching: an introduction, (in:) Crozet C., Liddicoat A. (eds.), Teaching language, teaching Culture. Canberra: ALAA, pp. 1-23.

Cut (2015), Thanksgiving. Native Americans. One word. [video] Online: https:// www.youtube.com/watch?v=jGc34FeFqH0 [Accessed 20.04.2020].

Deardorff D. K. (2011), Assessing intercultural competence. "New Directions for Institutional Research", No 149, pp. 65-79.

Duranti A. (2005), Ethnography of speaking: towards a linguistics of the praxis, (in:) Kiesling S. F., Paulston, C. B. (eds.), Intercultural discourse and communication: the Essential Readings. Oxford: Blackwell, pp. 17-32.

Duszak A. (1998), Tekst, dyskurs, komunikacja międzykulturowa. Warszawa: PWN. Eriksen T. H. (1991), The cultural contexts of ethnic differences. "Man", No 26(1), pp. 127-144.

Fitch K. L., Phillipsen G. (2009), Ethnography of speaking, (in:) Senft G., Ostman J., Verschueren J. (eds.), Culture and language use. Amsterdam: John Benjamin Publishing Company, pp. 121-130.

Frayne C. (2017), Wittgenstein, organic form, and orientation to intercultural games. "Journal of Intercultural Communication Research", No 46(2), pp. 147-160.

Geertz C. (1973), The interpretation of cultures. Selected essays. New York: Basic Books.

Grabowski C. (2008), Pursuit of happiness. The American dream, civil society, religion and popular culture. Lublin: Maria Curie-Skłodowska University Press. Green A. (1999), Keeping Britain in British studies. "Network", No 2, pp. 43-47. Hall J. K. (2012), Teaching and researching language and culture. London: Pearson Education.

Heller M. (2011), Paths to post-nationalism. A critical ethnography of language and identity. Oxford: Oxford University Press. 
Holmes P., O'Neill G. (2012), Developing and evaluating intercultural competence: Ethnographies of intercultural encounters. "International Journal of Intercultural Relations", No 36, pp. 707-718.

Hofstede G, Hofstede G.J, Minkov M. (2010), Cultures and organizations. Software of the mind. Intercultural cooperation and its importance for survival. New York: McGraw Hill.

Indian Country Today, (2019), \#NativeVote20: Watch the Frank La Mere Native American Presidential Forum Livestream here. Online: https://newsmaven.io/ indiancountrytoday/news/nativevote20-watch-the-frank-lamere-native-am erican-presidential-forum-livestream-here-F9GajeFPwEKns75isC-YPg/ [Accessed 20.04.2020].

Jenks C. (1993), Cultural reproduction. New York: Routledge.

Jenny's Wedding. (2015), [film] New York: Mary Agnes Donoghue.

Klus-Stańska D. (2012), Wiedza która zniewala - transmisyjne tradycje w szkolnej edukacji. „Forum Oświatowe”, No 1(46), pp. 21-40.

Knight C. (2014), Language and symbolic culture: an outcome of hunter-gatherer reverse dominance, (in:) Dor, D., Knight C., Lewis, J. (eds.), The social origins of language. Oxford: Oxford University Press. pp. 228-246.

Kramsch C. (2013), Culture in foreign language teaching. "Iranian Journal of Teaching Research", No 1(1), pp. 57-78.

Kramsch C. (2011), The symbolic dimension of the intercultural. "Language Teaching", No 44(3), pp. 354-367.

Kramsch C., Whiteside A. (2008), Language ecology in multilingual settings. Towards the theory of symbolic competence. "Applied Linguistics", No 29(4), pp. 645-671.

Language Education Policy Profile POLAND Online: https://rm.coe.int/langua ge-education-policy-profile-poland/16807b3c35 [Accessed 12.04.2020]. Liddicoat A. J. (2011) Language teaching and learning from an intercultural perspective, (in:) Hinkel E. (ed.), Handbook of research in second language learning and teaching. Vol. II. New York and London: Routledge, pp. 837-855.

Liddicoat A. J. et al. (2003), Report on intercultural language learning. Canberra: Commonwealth of Australia.

Loenhoff J. (2011), Tacit knowledge in intercultural communication. "Intercultural Communication Studies", No XX(1), pp. 57-64.

Lopez-Barrios M. (2012), Learners as ethnographers, informants and mediators: developing intercultural awareness through language teaching materials. "Electronic Journal of Foreign Language Teaching", No 9/Supplement 1, pp. 312-324.

Lucas J. (2017), I'm not racist. Atlantic Records. Online: https://www.azlyrics.com/ lyrics/joynerlucas/imnotaracist.html [Accessed 20.04.2020]. 
Ma L. (2004), Wittgenstein's language-game and intercultural communication. "Intercultural Communication Studies", No XIII (2), pp.100-112.

Merriam-Webster Dictionary. Online: https://www.merriam-webster.com/dic tionary/dictionary [Accessed 20.01.2020].

Moerman M. (1988), Talking culture. Berlin/New York: de Gruyter.

Newton J. et al. (2015), Intercultural communicative language teaching: implications for effective teaching and learning. A literature review and an evidence-based framework for effective teaching. Wellington: Victoria University of Wellington.

O’Driscoll J. (1995), Britain. Oxford: Oxford University Press.

Owczarek D. (2005), Tekst, realioznawstwo a kształcenie kompetencji interkulturowej wśród przyszłych nauczycieli, (in:) Mackiewicz M. (ed.), Dydaktyka języków obcych a kompetencja kulturowa i komunikacja interkulturowa. Poznań: Wydawnictwo Wyższej Szkoły Bankowej, pp. 97-102.

Prussing E. (2008), Reconfiguring the empty center: drinking, sobriety, and identity in native American women's narratives. "Culture Medicine and Psychiatry", No 31(4), pp. 499-526.

Risager K. (2011), Research timeline. The cultural dimensions of language teaching and learning. "Language Teaching", No 44(4), pp. 485-499.

Reimann A. (2010), Task-based cultural awareness raising through learner ethnographies, (in:) Shehadeh A., Coombe C. (eds.), Applications of task-based learning in TESOL. TESOL Publications, pp. 49-65.

Roberts C. et al. (2001), Language learners as ethnographers. Bristol: Multilingual Matters.

Robinson-Stuart G., Nocon H. (1996), Second culture acquisition: ethnography in the foreign language classroom. "The Modern Language Journal", No 80, pp. 432-449.

Rosaldo M. Z. (1982), The things we do with words: llongot speech acts and speech act theory in philosophy. "Language in Society", No 11(2), pp. 203-237.

Ryan Ph. (2009), Evolving intercultural identity during living and studying abroad: five Mexican women graduate students, (in:) Feng A., Byram M., Fleming M. (eds.), Becoming interculturally competent through education and training. Clevedon: Multilingual Matters, pp. 53-70.

Saravia-Shore M., Arvizu S. F. (2017), Cross-cultural literacy: an anthropological approach to dealing with diversity, (in:) Saravia-Shore M., Arvizu S. F. (eds), Cross-cultural literacy: ethnographies of communication in multiethnic classroom. London: Routledge, pp. XV- XXXVIII.

Sapir E. (2002), The psychology of culture. A course of lectures. Berlin: Mouton de Gruyter. 
Silverman D. (1993), Unfixing the subject. Viewing bad timing, (in:) Jenks, C. Cultural Reproduction. London: Routledge, pp. 163-187.

Stier J. (2006), Internationalisation, intercultural communication and intercultural competence. "Journal of Intercultural Communication", No 11(1), pp. 1-12.

The Graham Norton Show, (2013), [TV programme] Series 14 Episode 3: BBC One.

The Graham Norton Show, (2015), [TV programme] Series 16 Episode 18: BBC One. Turner M. (2001), Cognitive dimensions of social science: the way we think about politics, economics, law, and society. Oxford: Oxford University Press.

Waugh, L.R. et al. (2016), Critical discourse analysis: definition, approaches, relation to pragmatics, critique and trends, (in:) Capone A., Mey J.L. (eds.), Interdisciplinary studies in pragmatics, culture and society. Berlin: Springer, pp. 71-135.

Wells K. (2014), The geography of small talk. "The Atlantic". Online: https://www. theatlantic.com/video/index/359545/how-do-you-say-hello/ [Accessed 20.04.2020].

Wierzbicka A. (1999), Umysł-język - kultura. Warszawa: Wydawnictwo Naukowe PWN.

Wilczyńska E. (2002), Three approaches to teaching American life and civilisation: academic, integrational and vocational, (in:) Rydlewska J. (ed.), Cultural Curriculum. Theory Practice Trends. Szczecin: AMP Studio Paweł Majewski, pp. 127-138.

Zarate G. (1990), The observation diary: an ethnographic approach to teacher education, (in:) Buttjes D., Byram M. (eds.), Mediating Languages and Cultures: Towards an Intercultural Theory of Foreign Language Education. Clevedon: Multilingual Matters, pp. 248-260.

Zawadzka E. (2004), Nauczyciele języków obcych w dobie przemian. Kraków: Oficyna Wydawnicza Impuls. 